\title{
Effect of germination on biochemical changes in high yielding barley (Hordium vulgare $\mathrm{L}_{\text {.) }}$ varieties
}

\author{
M. M. Rahman ${ }^{1 *}$, S. S. Binte Salam ${ }^{2}$, U. Fatema Shahjadee ${ }^{1}$, A. Zerin Rupa ${ }^{1}$, M. Mashiar Rahman ${ }^{1}$ and \\ A. Kalam Azad ${ }^{2}$ \\ ${ }^{1}$ Institute of Food Science \& Technology, Bangladesh Council of Scientific \& Industrial Research, Dhaka-1205 \\ ${ }^{2}$ Department of Biotechnology and Genetic Engineering, Faculty of Applied Science and Technology, Islamic University, \\ Kushtia -7003, Bangladesh
}

Received: 12 November 2017

Revised: 14 February 2018

Accepted: 23 May 2018

DOI: http://dx.doi.org/10.3329/bjsir.v53i4.39196

\begin{abstract}
The effect of germination was evaluated on the nutritional properties and enzyme activities of three barley (Hordium vulgare L.) varieties namely BARI Barley-4, BARI Barley-5 and BARI Barley-7 produced by Bangladesh Agricultural Research Institute (BARI). The nutritional compositions and enzymatic activities ( $\alpha$-amylase and protease) in both raw and germinated seeds were changed gradually with germination period. Protein content of germinated seeds for BB-4, BB-5 and BB-7 was recorded as $13.65 \%, 14.34 \%$ and $13.95 \%$ respectively. Maximum increase of protein was $20.81 \%$ for BB-5 at 48 hours of germination. Gradual decrease was observed at 72 hours of germination and maximum decrease was $7.66 \%$ for BB- 5 but protein content was higher than non germinated seeds. Enzyme activity of $\alpha$-amylase and protease showed the results $2.20 \mathrm{U} / \mathrm{g}$ BB-5 and $1.16 \mathrm{U} / \mathrm{g}$ BB-4. Highest increase of $\alpha$-amylase and protease activity were found $125.53 \%$ for BB-7 and $107.55 \%$ for BB-5 at 48 hours of germination. The highest amount of total and reducing sugar was $12.58 \%$ for BB-5 and $1.97 \%$ for BB-7 respectively at 72 hours of germination. The maximum increase of total sugar was $240.00 \%$ and in reducing sugar it was $79.09 \%$ for BB-5 and BB-7 respectively. Highest calcium, phosphorus and iron contents were 39.70 (mg/100g), 273.91 $(\mathrm{mg} / 100 \mathrm{~g})$ and $8.37(\mathrm{mg} / 100 \mathrm{~g})$ for BB-4 and BB-7 respectively. The maximum increases of calcium and iron contents were $33.26 \%$ and $85.58 \%$ for BB-4 and BB-7 respectively at 48 hours of germination. Germinated barley seeds contain more protein with other easily digestible biomolecule than non germinated seeds.
\end{abstract}

Keywords: Germinated barley; Nutritional compositions and enzyme activities

\section{Introduction}

Barley (Hordeum vulgare L.) is of considerable nutritional significance to the human diet contributing a significant portion of the global human diet (Finnie and Svensson, 2009). Barley offers a wealth of potential health benefits (Baik and Ullrich, 2008) containing several vitamins and minerals including niacin (vitamin $\mathrm{B}_{3}$ ), thiamine (vitamin $\mathrm{B}_{1}$ ), selenium, calcium, iron, magnesium, zinc, phosphorus and copper. Barley has been proven to help improve certain health conditions. The antioxidants in barley work to slow down the rate of oxidative damage by gathering up free radicals that form when body cells use oxygen (Pins and Kaur, 2006). It is the fourth important cereal crop in the world and third important cereal in Bangladesh (FAOSTAT, 1993 -2002). It occupies about $9.4 \%$ of the total cereal acreage with about $7.8 \%$ of the total cereal production in the world (FAOSTAT, 2007). The total barley production in the world is 135.54 million tons in 2010 - 11 (Agro - stats, 2010). In 2013 -14, the total production of barley in the world was 140.10 million metric tons. 
In 2012 - 13, the production of barley in Bangladesh was 7000 metric tons (USDA, 2013). Seed germination is one of the oldest and most economical methods of producing and preserving food (Billings, 1998). During the germination of seeds, a massive breakdown of the reserve substances begin with the help of amylolitic, proteolytic and lipolytic enzymes and the products are transported to the growing seedlings for their development (Rahman et al., 2007). In addition, germination provides a natural way to reduce the volume of the material to be transported, to destroy undesirable components, to enhance the nutritive value and appearance of the seed (Simango, 1997). The initiation of protein synthesis in germinating seed is another important phenomenon. The highest content of protein was found in wheat, spring barley and spring triticale, which exceeded the content of protein found in winter triticale, winter barley and even in rye. Considering the above mentioned facts, the objectives of present investigation are to determine and compare the protein, mineral, starch, total sugar, reducing sugar and enzymatic activity (protease, $\alpha$-amylase) among different high yielding Barley varieties at different time intervals.

\section{Materials and methods}

\section{Barley seed sample collection}

Barley seed samples were collected from Bangladesh Agricultural Research Institute (BARI). All the apparatus were provided by the Food Enzymology Section, IFST, BCSIR, Dhaka-1205.Chemicals and solvents used in the study were of analytical reagents grade.

\section{Proximate analysis}

Among proximate analysis, protein content was determined using Macro-Kjeldahl AOAC method (2000). Other proximate analysis including fat, carbohydrate, ash, fibre and moisture contents of raw and germinated maize seeds were evaluated (Ranganna, 1991). Soxhlet apparatus was used for determination of fat by hexane and petroleum benzene $\left(40^{\circ} \mathrm{C}-60^{\circ} \mathrm{C}\right)$ extraction for 6 hours. Ash content was calculated by 6 hours of burning in muffle furnace at $600^{\circ} \mathrm{C}$. Moisture meter was used for determination of moisture content at $105 \pm 5^{\circ} \mathrm{C}$ temperature. Fiber content was measured by using $0.255 \mathrm{~N}$ H2SO4 and $0.313 \mathrm{~N} \mathrm{NaOH}$ solution. Starch, reducing sugar and total sugar contents of different seeds were determined by following the method of Ranganna (1991). The mineral content (calcium, phosphorus, and iron) were determined by the method of Anon. (1976).

\section{Enzyme activity assay}

Barley seeds $(0.5 \mathrm{~g})$ were grinded in a mortar with $0.1 \mathrm{M}$ phosphate buffer with respective $\mathrm{pH}$ (amylase 6.7 and protease $\mathrm{pH}$ 5.5) and finally crushed into paste using a homogenizer. The temperature was maintained at $4^{\circ} \mathrm{C}$ by putting ice in the outer chamber of the homogenizer. The suspension was then filtered through few layers of cheese cloth in cold room. The filtrate was then collected and clarified further by centrifuging at $10,000 \mathrm{rpm}$ for $15 \mathrm{~min}$ at $4^{\circ} \mathrm{C}$.

\section{Amylase}

Amylase activity was assayed following the method as described by Jayaraman (1981). One percent starch solution was used as substrate $(1.0 \mathrm{gm}$ in $100 \mathrm{ml}$ of $0.1 \mathrm{M}$ phosphate buffer, $\mathrm{pH}$ 6.7). The amylase activity was measured by estimating the release of maltose evaluated from the standard curve prepared with maltose. One unit of amylase activity was defined as the amount required for liberating $1.0 \mathrm{mg}$ of maltose in $15 \mathrm{~min}$ at $37^{\circ} \mathrm{C}$.

\section{Protease}

Protease activity was assayed following the modified method as describe by Mahadehvan and Sridhar (1982). Haemoglobin was used as substrate here. Protease activity was measured by estimating the amount of leucine released from haemoglobin. The amount of leucine released was calculated from the standard curve prepared with leucine. One unit of protease activity was defined as the amount required for liberating $1 \mathrm{mg}$ of leucine in $30 \mathrm{~min}$ at $37^{\circ} \mathrm{C}$.

\section{Results and discussion}

Barley is a potential cereal and germination is an inexpensive way to develop the food value therefore, it is very important to investigate the biochemical changes among three high varieties of barley. Proximate compositions from different varieties of non germinated barley seeds were analyzed shown in the Table I. The moisture content of BB-4, BB-5 and BB-7 were found $12.9 \%, 12.3 \%, 12.8 \%$ respectively. The result showed that 
ash content of barley seeds BB-4, BB-5, BB-7 were $2.08 \%, 2.16 \%$ and $2.21 \%$ respectively (Table I.). Ali et al. (1992) reported that ash content of barley seed was $3.90 \%$, which was similar to the result of the present study. The
(336.236 Kcal) followed by BB-5 (335.01 Kcal) and the lowest amount was found in BB-7 (333.617 Kcal). Fairbairn et al. (1999) observed the energy content of barley was $336 \mathrm{Kcal}$.

\section{Table I. Proximate composition of different varieties of barley seeds}

\begin{tabular}{cccc}
\hline Parameters & \multicolumn{3}{c}{ Name of varieties } \\
\cline { 2 - 4 } & BB - * $^{*}$ & BB - 5* & BB - 7* \\
Moisture (\%) & $12.9 \pm 0.01$ & $12.3 \pm 0.01$ & $12.8 \pm 0.01$ \\
Ash (\%) & $2.08 \pm 0.01$ & $2.16 \pm 0.01$ & $2.21 \pm 0.01$ \\
Protein (\%) & $11.40 \pm 0.02$ & $11.87 \pm 0.02$ & $11.65 \pm 0.01$ \\
Fat (\%) & $1.71 \pm 0.01$ & $1.68 \pm 0.01$ & $1.64 \pm 0.01$ \\
Crude Fibre (\%) & $5.18 \pm 0.01$ & $5.96 \pm 0.01$ & $5.77 \pm 0.02$ \\
Carbohydrate (\%) & $71.91 \pm 0.01$ & $71.99 \pm 0.02$ & $71.77 \pm 0.01$ \\
Energy & $336.236 \pm 0.01$ & $335.01 \pm 0.01$ & $333.617 \pm 0.01$ \\
(Kcal. per100 g) & & & \\
\hline
\end{tabular}

*Here, BB-4 = BARI Barley-4, BB-5 = BARI Barley-5, BB-7 = BARI Barley-7

$\pm=$ Standard deviation based on triplets

protein content of barley seed BB-4, BB-5 and BB-7 was found to be $11.40 \%, 11.87 \%$ and $11.65 \%$ respectively (Table I). The protein content found from this study were similar to the value $12.00 \%$ mentioned by Potter and Hotchkiss (1996) for protein content in barley. The fat content of barley seed for BB-4, BB-5, BB-7 was $1.71 \%$, $1.68 \%$ and $1.64 \%$ respectively (Table I). According to Kamal et al. (2013), fat content ranged from $1.5-2.9 \%$ almost similar to present study. The crude fibre contents of different barley seeds were varied from 5.18 to 5.96 $\%$.The BB-5 variety was found to have the highest fiber content $(5.96 \%)$ followed by BB-7 $(5.77 \%)$ and the lowest amount was found in BB -4 (5.18\%). Ijabadeniyi and Adebolu (2005) reported slightly lower values (2.07 $2.77 \%$ ) of the fibre content for the Zea mays L. varieties grown in Nigeria. Carbohydrate is the major chemical component of the $H$. vulgare seed. The carbohydrate content of BB-4, BB - 5, BB -7 was found to be $71.91 \%$, $71.99 \%$ and $71.77 \%$ respectively (Table I). The energy content was varied from 333.617 to $336.236 \%$. The energy content of BB-4 variety was found to be the highest
Mineral content of germinating barley seeds were shown in the Table II. The variety BB-4, BB-5 and BB-7 showed the gradual increase of calcium, phosphorus and iron contents till 48 hours then it was decreased at 72 hours of germination. The result found that maximum calcium content was $39.70 \mathrm{mg} / 100 \mathrm{gm}$ for BB-4 and the increase was $33.26 \%$. The result was in accord with Rupa et al. (2018). The variety of BB-7 showed the highest amount of phosphorus $273.91 \mathrm{mg} / 100 \mathrm{gm}$ at 48 hours of germination and lowest was found $268.11 \mathrm{mg} / 100 \mathrm{gm}$ for BB-5 variety. Phosphorus content of rice, barley and chickpea are almost similar obtained by Ibukun (2008). The phosphorus content in barley grown in Jordan, Morocco by the FAO ranges 179-350 (mg/100g). Maximum increase of phosphorus among the three barley seeds was $12.47 \%$ and maximum decrease was $9.51 \%$ found in BB-4 and BB-7 respectively.

BB-4, BB-5 and BB-7 variety showed highest iron content $8.37(\mathrm{mg} / 100 \mathrm{~g})$ for BB-7 after 48 hours of germination. The BB-7 variety showed the maximum increase and decrease of iron $85.59 \%$ at 48 hours of 
Table II. Mineral content of different varieties of barley seed during germination

\begin{tabular}{|c|c|c|c|c|c|}
\hline \multirow[t]{2}{*}{ Parameters } & \multirow[t]{2}{*}{ Variety } & \multicolumn{4}{|c|}{ Duration of germination } \\
\hline & & $0 \mathrm{hrs}$ & $24 \mathrm{hrs}$ & $48 \mathrm{hrs}$ & $72 \mathrm{hrs}$ \\
\hline \multirow{3}{*}{$\begin{array}{r}\text { Calcium } \\
(\mathrm{mg} / 100 \mathrm{~g})\end{array}$} & BB-4 & $29.79 \pm 0.01$ & $35.04 \pm 0.015$ & $39.70 \pm 0.02$ & $25.08 \pm 0.01$ \\
\hline & BB-5 & $27.04 \pm 0.01$ & $30.52 \pm 0.01$ & $35.03 \pm 0.02$ & $24.04 \pm 0.01$ \\
\hline & BB-7 & $26.05 \pm 0.01$ & $31.09 \pm 0.01$ & $33.80 \pm 0.01$ & $23.05 \pm 0.01$ \\
\hline \multirow{3}{*}{$\begin{array}{l}\text { Phosphorus } \\
\text { (mg/100g) }\end{array}$} & BB-4 & $240.43 \pm 0.01$ & $252.43 \pm 0.01$ & $270.3 \pm 0.01$ & $216.33 \pm 0.01$ \\
\hline & BB-5 & $239.35 \pm 0.01$ & $249.72 \pm 0.01$ & $268.11 \pm 0.02$ & $215.71 \pm 0.02$ \\
\hline & BB-7 & $242.5 \pm 0.01$ & $255.30 \pm 0.01$ & $273.91 \pm 0.01$ & $219.42 \pm 0.015$ \\
\hline \multirow{3}{*}{$\begin{array}{c}\text { Iron } \\
(\mathrm{mg} / 100 \mathrm{~g})\end{array}$} & BB-4 & $4.20 \pm 0.01$ & $5.81 \pm 0.01$ & $6.81 \pm 0.01$ & $5.64 \pm 0.03$ \\
\hline & BB-5 & $4.38 \pm 0.01$ & $5.50 \pm 0.01$ & $7.19 \pm 0.01$ & $5.79 \pm 0.01$ \\
\hline & BB-7 & $4.51 \pm 0.01$ & $5.88 \pm 0.02$ & $8.37 \pm 0.01$ & $6.39 \pm 0.01$ \\
\hline
\end{tabular}

$\pm=$ Standard deviation based on triplets

Table III. Protein and enzyme activity of barley seeds under different germination period

\begin{tabular}{lccccc}
\hline \multicolumn{1}{c}{ Test Parameters } & Variety & \multicolumn{4}{c}{ Duration of germination } \\
\hline & & $0 \mathrm{hrs}$ & $24 \mathrm{hrs}$ & $48 \mathrm{hrs}$ & $72 \mathrm{hrs}$ \\
& BB-4 & $11.40 \pm 0.02$ & $12.76 \pm 0.01$ & $13.65 \pm 0.01$ & $12.25 \pm 0.01$ \\
& BB-5 & $11.87 \pm 0.02$ & $13.26 \pm$ & $14.34 \pm 0.01$ & $12.78 \pm 0.02$ \\
& & & 0.01 & & \\
Protein (\%) & BB-7 & $11.65 \pm 0.01$ & $12.92 \pm .01$ & $13.95 \pm 0.01$ & $12.40 \pm 0.02$ \\
& BB-4 & $0.99 \pm 0.01$ & $1.53 \pm 0.02$ & $2.16 \pm 0.02$ & $1.39 \pm 0.01$ \\
& & & & & \\
& BB-5 & $1.03 \pm 0.01$ & $1.66 \pm 0.02$ & $2.20 \pm 0.02$ & $1.47 \pm 0.02$ \\
& BB-7 & $0.94 \pm 0.02$ & $1.73 \pm 0.02$ & $2.12 \pm 0.015$ & $1.41 \pm 0.01$ \\
& & & & & \\
& BB-4 & $0.56 \pm 0.02$ & $0.94 \pm 0.01$ & $1.16 \pm 0.01$ & $0.74 \pm 0.01$ \\
& BB-5 & $0.53 \pm 0.01$ & $0.89 \pm 0.01$ & $1.10 \pm 0.01$ & $0.68 \pm 0.01$ \\
& BB-7 & $0.57 \pm 0.01$ & $0.98 \pm 0.01$ & $1.13 \pm 0.01$ & $0.69 \pm 0.02$ \\
\hline
\end{tabular}

$\pm=$ Standard deviation based on triplets.

*Unit/g 
Table IV. Starch, total sugar and reducing sugar content of barley seeds during different germinating period

\begin{tabular}{|c|c|c|c|c|c|}
\hline \multirow[t]{2}{*}{ Test Parameters } & \multirow[t]{2}{*}{ Variety } & \multicolumn{4}{|c|}{ Duration of germination } \\
\hline & & $0 \mathrm{hrs}$ & $24 \mathrm{hrs}$ & $48 \mathrm{hrs}$ & $72 \mathrm{hrs}$ \\
\hline & BB-4 & $59.59 \pm 0.01$ & $39.18 \pm 0.01$ & $24.83 \pm 0.01$ & $16.08 \pm 0.02$ \\
\hline \multirow[t]{3}{*}{ Starch $(\%)$} & BB-5 & $60.54 \pm 0.01$ & $37.67 \pm 0.02$ & $23.47 \pm 0.02$ & $15.81 \pm 0.02$ \\
\hline & BB-7 & $62.64 \pm 0.01$ & $38.65 \pm 0.01$ & $24.67 \pm 0.02$ & $16.01 \pm 0.01$ \\
\hline & BB -4 & $3.43 \pm 0.01$ & $6.09 \pm 0.02$ & $8.70 \pm 0.01$ & $11.16 \pm 0.01$ \\
\hline \multirow[t]{3}{*}{ Total sugar $(\%)$} & BB-5 & $3.70 \pm 0.01$ & $6.56 \pm 0.02$ & $10.92 \pm 0.01$ & $12.58 \pm 0.01$ \\
\hline & BB-7 & $4.27 \pm 0.01$ & $7.14 \pm 0.02$ & $9.29 \pm 0.01$ & $11.94 \pm 0.01$ \\
\hline & BB-4 & $1.19 \pm 0.01$ & $1.44 \pm 0.02$ & $1.67 \pm 0.01$ & $1.98 \pm 0.02$ \\
\hline \multirow[t]{2}{*}{ Reducing sugar (\%) } & BB-5 & $1.14 \pm 0.02$ & $1.36 \pm 0.02$ & $1.58 \pm 0.01$ & $2.00 \pm 0.02$ \\
\hline & BB -7 & $1.10 \pm 0.01$ & $1.34 \pm 0.01$ & $1.57 \pm 0.02$ & $1.97 \pm 0.01$ \\
\hline
\end{tabular}

$\pm=$ Standard deviation based on triplets

germination and 41.68 in BB-7 at 72 hours of germination. Mubarak A.E. (2004) observed the Iron content of in the range of $8.0-9.70 \mathrm{mg} / 100 \mathrm{gm}$ in mungbean seeds which was closely related to this study.

Protein contents and enzyme activity of Barley seed under different germination conditions were summarized in the Table III. During different germination period, the gradual increase of protein content was observed. The highest protein content was $11.87 \%$ for BB-5. Compared to non germinated state ( 0 hours), the maximum increase of protein was $20.81 \%$ in BB-5 followed by BB-4 and BB-7 varieties which was then decreased after 72 hours of germination. Lowest protein content was found to be $12.40 \%$ while the decreased was $6.44 \%$ after $72 \mathrm{hrs}$.

Results showed that protein content increased at 24 and 48 hours of germination and then decreased with the progress of germination which was in accord with the results of Rahman et al. (2007) and Rupa et al. (2018). During different germination period, the highest $\alpha$-amylase activity was found for BB-5 (2.20 unit/g) and but the tremendous increase was $125.53 \%$ in BB-7 followed by BB-4 and BB-5.Then amylase activity was decreased after 72 hours of germination and the maximum decrease was $50.0 \%$ for BB-7. The results are in agreement with Liza et al. (2010) who reported that the $\alpha$-amylase activities increased at 24 and 48 hours of germination in chickpea and then decreased drastically from 72 hours.

The highest protease activity 1.16 unit/g was found at 48 hours in BB-4 among three high yielding barley varieties while the protease activity decreased drastically at 72 hours due to germination. In this regard, the maximum increase of protease activity was found $107.55 \%$ for BB-5 at 48 hours while the protease activity was decreased maximum 32.14\% (0.74 unit/g) after 72 hours germination. According to Rahman et al. (2007), the protease activity of mungbean increased tremendously from $131 \%$ to $161 \%$ at 24 hours of germination and 
thereafter decreased, supports the above mentioned results. Rahman et al. (2007) showed that $\alpha$-amylase and protease activity of mungbeans increased at 24 hours of germination and then decreased gradually. Those above observation were similar with the present research.

Results of starch, total sugar and reducing sugar content of barley seed during different germinating period were shown in Table IV.

It was observed that due to germination, starch content of three Barley varieties decreased gradually from 24 to 72 hours. The decrease content of starch was $16.08 \%$ whereas the percent was $73.02 \%$ found in BB-4 followed by BB-5 and BB-7 at 72 hours of germination. Results are available that starch content decreased with the time progress of germination which is in accord with the result of Kashem et al. (1995) and Tuna et al. (2017).

The changes of total sugar and free sugar contents of barley seed were shown in Table IV. From the data it was observed that total sugar and free sugar contents were also increased gradually from 24 to 72 hours of germination. The highest total sugar content was $12.58 \%$ for BB-5 and lowest content was $11.94 \%$ for BB-7 while the maximum increase of was $240.0 \%$ in BB-5 followed by BB-4 and BB-7 varieties.

A similar trend in sugar content of maize seeds during germination has been observed. It was observed that during germination, reducing sugar content increased gradually from 24 to 72 hours of germination. The varieties BB-4, BB-5 and BB-7 showed the increases in reducing sugar $1.98 \%, 2.00 \%$ and $1.97 \%$ respectively at 72 hours of germination. The maximum increase of reducing sugar content was $79.09 \%$ in BB-7 followed by BB-5 and BB-4 varieties. Results are available that reducing sugar content increased with the period of germination which is in accord with the result of Kashem et al. (1995) and Tuna et al. (2017).

\section{Conclusion}

As one of the first cultivated cereals, barley is fairly suitable for further research because of its short life cycle and physiological characteristics. This study results demonstrated that barley is a cereal products containing higher nutritional values and easy to use to germinate. Barley, a minor crop, could be emerged as a major one because of its nutritional value. Agriculture scientist of Bangladesh could play an important role in enhancing the production of germinated barley together with food items made from it which in turn would contribute to food security as well as earning foreign currency.

\section{Acknowledgement}

Authors wish to thank BCSIR and the Department of Biotechnology and Genetic Engineering, Islami University, Kushtia for giving the chance to complete the research work at Food Enzymology Section, IFST, BCSIR, Dhaka-1205.

\section{Reference}

Agro-stats (2010), World barley production consumption and stocks. www.agrostats. com/ world statistics/world barley html.

Ali PS, Malek PM, Jahan PK and Salamtullah DK (1992), Nutrient value of country food, Institute of Food Science and Technology, pp 2-30.

Anonymous (1976), Manual of Laboratory Techniques, National Institute of Nutrition, Indian Council of Medical Research, Hyderabad - 500007, India, pp 3-5.

Baik BK and Ullrich SE (2008), Barley for food characteristics, improvement and renewed interest, J. Cereal Science 48: 233-242. DOI: org/10. 1016/j.jcs.2008.02.002

Billings T (1998), On Fermented Foods http://living-foods.com.

Edeogu CO, Ezeonu FC, Okaka ANC, Ekuma CE and EIom SO (2007), Proximate Compositions of Staple Food Crops in Ebonyi State, South Eastern Nigeria, Int. J. Biotechnol. Biochem.1: 1-8.

FAO (2007), http://www.fao.org.

Sharma P and Gujral HS (2010), Milling behavior of hulled barley and its thermal and pasting properties, J. Food Eng. 97: 329-334. DOI: org/10. 
1016/j.jfoodeng.2009.10.025V

Fairbairn SL, Patience JF, Classen HL and Zijlstra RT (1999), The energy content of barley fed to growing pigs: characterizing the nature of its variability and developing prediction equations for its estimation, J. Anim. Sci. 6: 1502-1512.

FAOSTAT (1993-2002), Statistics database. Online: Subset Production within Agriculture database. Available at http://apps.fao.org.

FAO and FAOSTAT (1993-2002), Statistics database, Online: Subset Production within Agriculture database http://apps.fao.org

Finnie C and Svensson B (2009), Barley Seed Proteomics from Spots to Structures, J. Pro. 72: 315-324. DOI: org/10.1016/j.jprot.2008.12.001

Ibukun EO (2008), Effect of prolonged parboiling duration on proximate composition of rice, Sci. Res. Ess. 3(7): 323-325.

Ijabadeniyi AO and Adebolu TT (2005), The effect of processing methods on the nutritional properties of ogi produced from three maize varieties, J. Food Agric.and Environ. 3: 108-109.

Jayaraman J (1981), Laboratory Manual in Bio-chemistry, Wiley Eastern Ltd., New Delhi, India.

Kamal MEY, El-Fishawy FAEK, Ramadan ESAN, Asmaa M and Rahman AE (2013), Nutritional Assessment of Barley, Talbina and Their Germinated Products, Food Sci. \&Tech Dept, Faculty of Agric., Assiut Uni, Assiut, Egypt Frontiers in Science 3(2): 56-65. DOI: 10.5923/ j.fs. 20130302.02

Kashem AM, Sultana N, Samanta C and Kamal AMA (1995), Starch, Sugar, Amylase and Invertase activity in the Germination Seeds of Modern Wheat Varieties, J.Natn.Sci.Coun.SriLanka., 23(2): 55-60.
Liza SSR, Rahman SMB, Shahjadee UF, Rahman MM, and Uddin MN (2010), Enzyme activity of chickpea during germination, Ban. J. Life Sci. 22(1): $43-47$.

Mahdy EL and Sebaiy EL (1983), Changes in carbohydrates of germinating fenugreek seeds (Trigonellafoenumgraecum L.), J. Sci. food Agri. 34(9): 951-956. DOI: org/10.1002/jsfa. 2740340909

Mahadevan A and Sridhar R (1982), Methods of physiological plant pathology, $2^{\text {nd }}$ Ed., Sivakasi publication, Madras, India, p 316.

Millerd A and Thomson J (1975), Storage protein of legume seeds: Proteins of legume seeds: Potential for change, CSIRO Div. of Plant Industry Genetics Report 3: 58-68.

Mubarak AE (2005), Nutritional composition and antinutritional factors of mung bean seeds (Phaseolus aureus) as affected by some home traditional processes, Food Chem. 89: 489-495. DOI: org/10.1016/j.foodchem.2004.01.007

Pins JJ and Kaur H ( 2006), A review of the effects of barley beta-glucan on cardiovascular and diabetic risk, J Cereal Foods World 51: 8

Potter NN and Hotchkiss JH (1996), Food Science, $5^{\text {th }}$ Ed., International Thomson Publishing, pp 382-391.

Rupa AZ, Sarker P, Rahman MM, Shahjadee UF, Rahman MM and Rahman MM (2018), Study of the effect of germination and the stability of the enzymes of different varieties of Zea mays L. seed, Food Res. 2(1): 78-81.

Rahman MM, Banu LA, Rahman MM and Shahjadee UF (2007), Changes of the Enzymes Activity during Germination of Different Mung bean Varieties. Ban. J. Sci. Ind. Res. 42(2): 213-216. DOI: org/10. 3329/bjsir.v42i2.474 
Ranganna S (1991), Proximate composition In: Tuna KF (2017), Nutritional changes during Hand book of analysis and quality control for fruit and vegetable products, Tata McGraw-Hill, pp 12-27.

Simango C (1997), Potential use of traditional fermented foods for weaning in Zimbabwe, J. Soc. Sci. and Med. 44: 1065-1068. germination and the stability of enzymes of immature and mature green pea (Pisum sativum L.), M.S. Thesis, Patuakhali Science and Technology University, Dumki, Patuakhali, pp 20-23.

USDA (United States Department of Agriculture) (2013), www.indexmundi.com/agriculture/country barley production 